\title{
Clostridium Cluster XIV
}

National Cancer Institute

\section{Source}

National Cancer Institute. Clostridium Cluster XIV. NCI Thesaurus. Code C129413.

A group comprised of more than 20 bacterial species, most are in the Clostridium genus but a few are outside the Clostridium genus. This cluster is based on comparative sequence analysis of their $16 \mathrm{~S}$ ribosomal RNA gene sequences. Some of these species are commensal in humans. 